\title{
Study of Thyroid Lesions by Fine Needle Aspiration Cytology and its Correlation with Thyroid Function Test
}

\author{
Anuj Poudel, a,c SK Jain ${ }^{\mathrm{b} . c}$
}

\begin{abstract}
:
Introduction: Fine needle aspiration cytology (FNAC) of the thyroid gland has been widely and successfully utilized for diagnosis. Assessment of thyroid pathology is even more informative if correlated with thyroid function tests (TFT). This study aims to compare the efficacy of fine needle aspiration cytology with thyroid function tests in different thyroid lesions. Methods: A descriptive study was carried out among the patients who presented with thyroid swelling visiting Department of Ear Nose Throat (ENT) of Lumbini Medical College and Teaching Hospital (LMCTH) from June 2012 to February 2013. The study population were selected on random basis. A total of fifty patients involved in the study and were sent to Department of Pathology for FNAC and TFT. Results: Most of the cases (44\%) of thyroid swelling were from 21 to 40 years of age. Among them, $86 \%$ were females. Out of total respondents, $48 \%$ were found to be colloid goiter. 70\% findings of FNAC and TFT were in accordance. Conclusions: The findings of FNAC and TFT were found to be significantly associated (P value $<0.05$ ).
\end{abstract}

Keywords: fine needle aspiration • hyperthyroidism • hypothyroidism • thyroid function test

\section{INTRODUCTION:}

FNAC of the thyroid gland is now wellestablished, first line diagnostic test for the evaluation of thyroid lesions with the main purpose of confirming the type of thyroid lesion and thereby, reducing unnecessary surgery. ${ }^{1}$ Although there is a large body of world literature claiming the accuracy and usefulness of thyroid cytology, there is also evidence showing possible limitations and pitfalls of this procedure. ${ }^{2,3}$ In view of this, we compared cytomorphological details with Thyroid Function Test (TFT). We scrutinized the cases showing any discrepancy in cytology findings with TFT with aim

a - Lecturer

b - Professor

c - Department of Pathology

Lumbini Medical College Teaching Hospital, Palpa, Nepal

Corresponding Author:

Dr. Anuj Poudel

e-mail: dranuj2002@yahoo.co.in

How to cite this article:

Poudel A, Jain SK. Study of thyroid lesions by fine needle aspiration cytology and its correlation with thyroid function test. Journal of Lumbini Medical College. 2013;1(1):28-30. doi:10.22502/jlmc.v1i1.9. of establishing possible causes of the errors.

\section{METHODS:}

A descriptive study was conducted among 50 patients who presented with swelling in the thyroid region in the Department of ENT of Lumbini Medical College and Teaching Hospital (LMCTH) during June 2012 to Feb 2013. They were then sent to Pathology Department for TFT and FNAC. The procedure was explained to the patient and verbal consent was obtained prior to performing the procedure. These patients were subjected to FNAC using 23/24-gauge needle and $10 \mathrm{cc}$ sterilized and disposable plastic syringes after taking all aseptic precautions. ${ }^{4}$ All slides were stained by Wright method and thyroid function test was performed by clia. ${ }^{5}$ Diagnosis of cytological smears were done according to standard criteria defined by Sidaway. ${ }^{6}$ Cases with cytological and thyroid function tests disparity were selected and were re-evaluated for the detection of possible causes of failure. Necessary descriptive statistics (percentage, frequency) including inferential statistics (Pearson $X^{2}$ test) to compare the association between categorical data 
were calculated using SPSS 16. P-value $<0.05$ was regarded as statistically significant.

\section{RESULTS:}

Among the total thyroid swelling cases, $86 \%$ were female and $14 \%$ were male (Table 1 ). $44 \%$ of thyroid swelling cases were from the age group of 21 to 40 years (Table 2). 58\% and $42 \%$ patients had nodular and diffuse swelling respectively (Table 3). Among the FNAC results, $48 \%$ colloid goiters were found in study population (Table 4). $70 \%$ of thyroid function test results (T3, T4 and TSH) were in accordance to cytomorphological study (P value $<0.05$ ) and $30 \%$ of results were not in accordance (Table 5).

\section{DISCUSSION:}

FNAC is an inexpensive, simple and rapid method of obtaining pathological diagnosis that is particularly suitable for use in the resource-poor setting. ${ }^{7}$ The numerous diagnostic procedures currently available improve the anatomic, pathologic, radiologic and functional assessment of the thyroid swelling but may also lead to unjustified increase in cost with little practical gain, if not used rationally. As most of the hospitals lack some of these ancillary diagnostic investigations, FNAC is still regarded as the single most accurate and cost-effective procedure. It is well known that a thyroid function results varies according to the different thyroid lesions. It can

Table 1: cross tabulation of sex and TFT

\begin{tabular}{|l|l|c|c|c|c|c|c|c|c|}
\hline \multicolumn{7}{|l|}{} & \multicolumn{7}{|c|}{ Function } & \multirow{2}{*}{ Total } \\
\hline & & $\begin{array}{c}\text { Primary } \\
\text { Hyperthyroidism }\end{array}$ & $\begin{array}{c}\text { Subclinical } \\
\text { Hypothyroidism }\end{array}$ & Euthyroid & $\begin{array}{c}\text { T3 } \\
\text { Toxicosis }\end{array}$ & $\begin{array}{c}\text { Subclinical } \\
\text { Hyperthyroidism }\end{array}$ & $\begin{array}{c}\text { Not } \\
\text { Conclusive }\end{array}$ & $\begin{array}{c}\text { Primary } \\
\text { Hypothyroidism }\end{array}$ & N=50(\%) \\
\hline \multirow{2}{*}{ Sex } & Male & 2 & 1 & 3 & 1 & 0 & 0 & 0 & $7(14 \%)$ \\
\cline { 2 - 10 } & Female & 8 & 3 & 13 & 0 & 2 & 15 & 2 & $43(86 \%)$ \\
\hline \multicolumn{2}{|l|}{ Total } & $10(20 \%)$ & $4(8 \%)$ & $16(32 \%)$ & $1(2 \%)$ & $2(4 \%)$ & $15(30 \%)$ & $2(4 \%)$ & $50(100 \%)$ \\
\hline
\end{tabular}

Table 2: Age distribution of patients

\begin{tabular}{|l|l|l|}
\hline \multicolumn{1}{|c|}{ Age } & $\begin{array}{c}\text { Number of patients } \\
(\mathbf{N}=50)\end{array}$ & \multicolumn{1}{|c|}{$\begin{array}{c}\text { Percentage } \\
(\%)\end{array}$} \\
\hline $10-20$ years & 3 & $6 \%$ \\
\hline $21-40$ years & 22 & $44 \%$ \\
\hline $41-60$ years & 21 & $42 \%$ \\
\hline $61-80$ years & 4 & $8 \%$ \\
\hline
\end{tabular}

range from hypo to hyperthyroidism, euthyroidism to subclinical hypo- and hyperthyroidism.

In the present study, out of 50 cases of thyroid lesions, the findings of FNAC and TFT were in correlation with each other in $35(70 \%)$ cases. In $15(30 \%)$ cases, the findings of FNAC were not in accordance with TFT. Out of 24 cases of colloid

Table 3: Cross tabulation between swelling and TFT

\begin{tabular}{|c|c|c|c|c|c|c|c|c|c|}
\hline & \multicolumn{7}{|c|}{ Function } & \multirow{2}{*}{$\begin{array}{l}\text { Total } \\
n=50\end{array}$} \\
\hline & & $\begin{array}{c}\text { primary } \\
\text { hyperthyroidism }\end{array}$ & $\begin{array}{c}\text { subclinical } \\
\text { hypothyroidism }\end{array}$ & euthyroid & t3 toxicosis & $\begin{array}{c}\text { subclinical } \\
\text { hyperthyroidism }\end{array}$ & $\begin{array}{c}\text { not } \\
\text { conclusive }\end{array}$ & $\begin{array}{c}\text { primary } \\
\text { hypothyroidism }\end{array}$ & \\
\hline \multirow{2}{*}{ Swelling } & nodular & 6 & 2 & 12 & 0 & 1 & 7 & 1 & $29(58 \%)$ \\
\hline & diffuse & 4 & 2 & 4 & 1 & 1 & 8 & 1 & $21(42 \%)$ \\
\hline \multicolumn{2}{|c|}{ Total } & $10(20 \%)$ & $4(8 \%)$ & $16(32 \%)$ & $1(2 \%)$ & $2(4 \%)$ & $15(30 \%)$ & $2(4 \%)$ & $50(100 \%)$ \\
\hline
\end{tabular}

Table 4: cross tabulation between FNAC and TFT

\begin{tabular}{|c|c|c|c|c|c|c|c|c|}
\hline \multirow[b]{2}{*}{ FNAC results } & \multicolumn{7}{|c|}{ Function } & \multirow{2}{*}{$\begin{array}{c}\text { Total } \\
N=50(\%)\end{array}$} \\
\hline & $\begin{array}{c}\text { Primary } \\
\text { Hyperthyroidism }\end{array}$ & $\begin{array}{c}\text { Subclinical } \\
\text { Hypothyroidism }\end{array}$ & Euthyroid & $\begin{array}{c}\text { T3 } \\
\text { Toxicosis } \\
\end{array}$ & $\begin{array}{c}\text { Subclinical } \\
\text { Hyperthyroidism }\end{array}$ & $\begin{array}{c}\text { Not } \\
\text { Conclusive }\end{array}$ & $\begin{array}{c}\text { Primary } \\
\text { Hypothyroidism }\end{array}$ & \\
\hline Colloid goiter & 3 & 1 & 9 & 0 & 1 & 10 & 0 & $24(48 \%)$ \\
\hline Thyroiditis & 4 & 1 & 1 & 0 & 1 & 4 & 2 & $13(26 \%)$ \\
\hline Graves disease & 1 & 0 & 0 & 1 & 0 & 0 & 0 & $2(4 \%)$ \\
\hline Papillary carcinoma & 2 & 0 & 2 & 0 & 0 & 0 & 0 & $4(8 \%)$ \\
\hline No opinion possible & 0 & 1 & 1 & 0 & 0 & 0 & 0 & $2(4 \%)$ \\
\hline Infected thyroid cyst & 0 & 1 & 0 & 0 & 0 & 0 & 0 & $1(2 \%)$ \\
\hline Follicular neoplasm & 0 & 0 & 2 & 0 & 0 & 0 & 0 & $2(4 \%)$ \\
\hline Hurthle cell neoplasm & 0 & 0 & 1 & 0 & 0 & 1 & 0 & $2(4 \%)$ \\
\hline Total & $10(20 \%)$ & $4(8 \%)$ & $16(32 \%)$ & $1(2 \%)$ & $2(4 \%)$ & $15(30 \%)$ & $2(4 \%)$ & $50(100 \%)$ \\
\hline
\end{tabular}


goiter, FNAC and TFT results were in correlation in $21(87.5 \%)$ cases and findings were not in correlation in $3(12.5 \%)$ cases. Similar findings were found in thyroiditis. The FNAC findings were well in correlation with TFT in ten $(76.9 \%)$ cases and in accordance in three $(23.1 \%)$ cases.

There are few studies that focused on cytomorphology and serologic correlation. Singh N. conducted a study of 150 cases in Jawaharlal Institute of Postgraduate Medical Education and Research Centre, which reported that fireflares and macrophages in FNAC correlates positively with hyperthyroidism with $\mathrm{p}$ values of 0.002 and 0.005 respectively. ${ }^{8}$ Results from our study also reflect the similar picture. Chehade JM conducted a study at University of Florida, College of Medicine found that there was a high degree of concordance between serological and cytological findings of lymphocytic thyroiditis in people with nodular colloid goiter. ${ }^{9}$ Similarly Luiz HV reported a case of thyroid tuberculosis under FNAC along with thyroid function which was consistent with subclinical hyperthyroidism that subsequently evolved into hypothyroidism. ${ }^{10}$ One of the most difficult aspects sometimes is to correlate cytomorphological details with that of TFT when

\section{REFERENCES:}

1. Orell SR. In: Orell SR, Sterrette GF, Walters MN, Whitakar D. (eds). Manual and atlas of fine needle aspiration cytology (4th ed.). New Delhi: Churchill-Livingstone; 2005. p.125-64.

2. Hamburger JI, Husain M, Nishiyama R, Nunez C, Solomon D. Increasing the accuracy of the fine needle biopsy for the thyroid nodules. Arch Pathol Lab Med. 1989;113:1035-41.

3. Reagan LR, Farkas T, Dehner LP. Fine needle aspiration of the thyroid: a cytohistologic correlation and study of discrepant cases. Thyroid. 2004;14:35-41.

4. Smit TJ, Sefali H, Foster EA, Reinhold RB. Accuracy and cost-effectiveness of fine needle aspiration biopsy. Am J Surg. 1985; 149:540-5.

5. Hall TL, Layfield LJ, Philippe A, Rosenthal DL. Sources of diagnostic error in fine needle aspiration of thyroid. Cancer.1989;63:718-25.

6. Sidaway MK, DelVecchio DM, Knoll SM. Fine needle aspiration of thyroid nodules: correlation between cytology and histology and evaluation of discrepant cases. Cancer.1997;81:253-9.

7. Das DK. Fine needle aspiration cytology: its origin, development and present status with special reference to developing country, India. Diagn Cytopathol. 2003;28:345-51. the findings do not correlate with each other as in our study $30 \%$ of cases were discordant. FNAC can effectively diagnose thyroid lesions and the like malignant tumor of thyroid endocrine systemPapillary carcinoma. Unfortunately, this is not always the case; the diagnosis of thyroid lesions and their clinical management is highly dependent upon many variables such as: the physical characteristics of thyroid lesion, operator experience (i.e., the individual performing FNAC and interpreting the cytomorphology) and thyroid hormone replacement therapy. ${ }^{11-15}$

\section{CONCLUSION:}

There were significant correlations of results between TFT and FNAC although, some discordance was found between these two parameters. In spite of the high levels of awareness about performing TFT and FNAC, the level of awareness could not be matched by a corresponding high level of utilization by these tests. FNAC and serological evaluation demonstrate cost advantage and high accuracy, benefits patient's care and cost-containment efforts in the centers with limited diagnostic facilities.

8. Singh N, Kumar S, Negi VS, Siddaraju N. Cytomorphologic study of Hashimoto's thyroiditis and its serologic correlation: a study of 150 cases: Acta cytol. 2009;53(5):507-16.

9. Chehade JM, Lim W, Silverberg AB, Mooradian AD. The incidence of Hashimoto's disease in nodular goiter: the concordance in serological and cytological findings. Int J Clin Pract. 2010; 64(1):29-33.

10. Luiz HV, Pereira BD, Silva TN, Veloza A, Matos C. Thyroid Tuberculosis with Abnormal Thyroid Function- case report and review of literature. Endocr Pract. 2013;21:1-15.

11. Cronan JJ. Thyroid nodules: Is it time to turn off the US machines? Radiol. 2008;247:602-4.

12. Kini SR. Color atlas of differential diagnosis in exfoliative and aspiration cytopathology. Philadelphia: Lippincott Williams \& Wilkins; 2011. Xvii, p: 1015.

13. Oertel YC. A pathologist's comment on diagnosis of thyroid nodules by fine needle aspiration. J Clin Endocrino Metabol. 1995;80:1467-8.

14. Oertel YC. Who should perform fine-needle aspirations? Cytopathol. 1997;8:134-8.

15. Oertel YC. Fine-needle aspiration in the evaluation of thyroid neoplasm. Endocr pathol. 1997;8:215-24. 